\title{
Post M\&A Accounting Performance of Romanian Banks
}

\author{
Maria Carmen Huian
}

Alexandru Ioan Cuza University of Iasi, lasi, Romania

\begin{abstract}
The purpose of this paper is to assess the financial performance of Romanian banks involved in M\&A activities, as target banks, over a period of 10 years (1998-2008). Performance is analyzed in terms of profitability by using traditional accounting measures: ROE, ROA and NIM. Post-M\&A performance for a 3-year period is compared with the aggregate ratios from all Romanian banks. The findings are mixed. On one hand, bank M\&A in Romania does not result in improved ROE or ROA in the post M\&A 3-year period under review. On the other hand, merged banks report media NIM above industry.
\end{abstract}

Keywords: mergers and acquisitions, performance, profitability, ROE, NIM.

\section{Introduction}

In this paper, the researcher examines the post-transaction performance of the Romanian banks involved in merger and acquisition (M\&A) activities by using accounting profitability ratios. The present work is motivated by the relative shortage of empirical evidence on the impact of mergers and acquisitions on Romanian banks. The current stream of literature dealing with the effects of M\&As on Romanian banks consists of regional analyses (among other Eastern European countries), such as those of Bonin et al., 2003 and 2005; Clarke et al., 2005, or cross-border analyses (Correa, 2008; Beccalli and Frantz, 2008). In addition, there is a handful of studies assessing the Romanian banking performance in general, regardless of the M\&A operations (Grigorian and Manole, 2002; Asaftei and Kumbhakar, 2007; Gondor and Munteanu, 2010). Nevertheless, the aforementioned studies do not explicitly focus on the impact of M\&As on the accounting profitability of the Romanian banking institutions. This paper therefore aims to fill in this gap.

To our knowledge, this is the first study to deal with post-M\&A profitability of target banks located in Romania based on accounting information. Specifically, it focuses on merger and acquisition deals that took place in the period of 1998-2008, involving only commercial banks. The researcher measures performance by using an indicator capturing bank profitability: return on equity (ROE) further decomposed according to the DuPont model. The researcher also calculates net interest margin (NIM) of the selected banks.

The present paper is organized as follows. Section 1 briefly describes the development of the Romanian banking system. In section 2 , the main findings of the relevant literature

Copyright (C) 2012 Maria Carmen Huian. This is an open access article distributed under the Creative Commons Attribution License unported 3.0, which permits unrestricted use, distribution, and reproduction in any medium, provided that original work is properly cited. Contact author: Maria Carmen Huian E-mail: maria.huian@uaic.ro 
dealing with post-M\&A effects on banks performance are summarized. Section 3 presents the accounting profitability ratios used. The sample and methodology are described in section 4 , while the empirical results are presented in section 5. Section 6 concludes.

\section{Romanian Banking System}

After the fall of the communism, Romanian authorities made several attempts to reform the national economy and to develop a healthy banking system. This process involved a major reorganization of the financial industry which mainly comprised, until late 1990s, a small number of stateowned banks and banks with domestic private capital. In the beginning of the transition period, banks' primary role was to channel their funds to some loss-making state-owned enterprises (Asaftei and Kumbhakar, 2007), without much evaluation of the credit conditions of their clients. The result was a significant share of nonperforming loans which, alongside risky practices, mismanagement, "delays in restructuring and privatization, difficulties endangered by several bankruptcies and the collapse of the largest investment fund" (NBR 2000), severely affected the financial soundness of the banking sector. Therefore, a stronger supervision and the establishment of a better regulatory framework, as efforts to ensure financial stability, were much needed. The National Bank of Romania assumed this important role and its efforts of enhancing the regulatory system and strengthening the prudential supervision started to pay off in the beginning of the new millennium. The pace of banks' restructuring and privatization increased, foreign banks entered the market, thus increasing the competition, the general state of the national economy improved. All these changes resulted not only in a larger volume of banking activity and a better financial stability of the sector, but also in an increase in terms of financial intermediation and in a wider range and sophistication of financial services (Grigorian and Manole, 2002).
Romania's admission to the European Union in January 2007 was a turning point in the evolution of the national economy and the banking system. It triggered a significant strengthening of competition among banks, entailing structural changes. In this new competition-driven environment, doubled by the years of economic boom (2004-2007), the main focus of the banking system became gaining a bigger market share. In order to achieve this goal, banks expanded their products (by providing both newly-created products and special offers whose accessibility and extra facilities made them more attractive) and territorial networks. In their effort to increase their market share, "credit institutions kept boosting their lending activity even after the onset of the global financial turmoil" (NBR 2007). Initially, Romanian financial institutions performed surprisingly well during the first stages of the crisis. This was explained by the small portion of financial securities held "over the past few years, trading portfolios in the Romanian banking system accounted for less than 3 percent of total investments" (Dardac and Moinescu, 2009) and by the lack of toxic assets arising from the securitization of subprime credit packages (Isarescu, 2008). Eventually, the financial crisis and the worsening of the macroeconomic climate made an impact on the Romanian credit institutions. Therefore, in 2008, the banking system switched from excess liquidity to liquidity shortfall, and from aggressive lending to promotions aimed at attracting deposits (NBR 2008).

The general factors that led to the global economic crisis also caused banking business to slow down. The loan market witnessed a significant stagnation, and the quality of the loan portfolio worsened worryingly. Although non-performing claims were at a manageable level, their growth rate raised concerns for financial stability (NBR [a] 2010). Still, so far there was no need for banks' capitalization with public funds. Moreover, national authorities claim that currently, Romanian banking system may be deemed as stable, with capitalization, 
solvency and liquidity levels in line with prudential requirements (NBR [b] 2010). Yet, in 2010 profitability entered a negative territory. After a severe decrease of profits in 2009, many banks reported losses in 2010. This situation was ascribed mainly to the unprecedented provisioning costs. The falling trend of reported earnings was alleviated by some measures taken to reduce expenses: banks started to better control their costs by cutting down the number of units and employees and by putting on hold their investment plans. The drastic economic measures initiated by the government in 2010 and the persistent recession significantly impacted the risk appetite of banks and even changed their business model (it shifted towards lending mainly non-financial companies).

\section{Literature Review}

According to Altunbas and Ibanez (2004) and Focarelli et al. (2002), most of the studies measuring the level of success of bank mergers and acquisitions in terms of financial performance follow two main empirical methods.

The first group analyzes the impact of M\&As by making comparisons of pre-merger and post-merger performance. Berger et al. (1999) divide these studies into static analyses (studies that relate the potential consequences of consolidation to certain characteristics of financial institutions that are associated with consolidation, such as institution size; although they do not use data on M\&As, they may prove useful in predicting the consequences of M\&As) and dynamic analyses (studies that compare the behavior of financial institutions before and after M\&As or compare the behavior of recently consolidated institutions with other institutions that have not recently engaged in M\&As). Regarding the latter, Huizinga et al. (2001) make a distinction between studies analyzing the impact of M\&As with performance ratios based on accounting variables (Rhoades, 1993; Ramaswamy, 1997; Mylonidis and Kelnikola, 2005; Correa,
2008; Badreldin and Kalhoefer, 2009) and studies investigating the evolution of the cost and profit X-efficiency relative to a shifting industry benchmark for merging and nonmerging banks (Berger and Humprey, 1992; Huizinga et al., 2001; Vander Vennet, 2003; Koetter, 2005; Ekkayokkaya et al., 2009). In addition, a number of studies combine the two approaches by comparing pre- and postmerger levels of simple accounting ratios with more complicated frontier-based (cost or profit) efficiency (Pilloff, 1996; Beccalli and Frantz, 2008; Lozano-Vivas and Weill, 2009).

The second group of studies investigating the effects on bank M\&As takes a more comprehensive approach and uses eventstudy methodology (examination of the market reaction to merger announcements through the analysis of changes in share/bonds prices) (Cybo-Ottone and Murgia, 2000; Knapp et al., 2005; DeLong and DeYoung, 2007) [1]. Moreover, there are papers that combine dynamic analyses and event-study methodology (Healy et al., 1992; Cornett and Tehranian, 1992, Campa and Hernando 2005, Mylonidis and Kelnikola 2005).

As our paper falls under the dynamic analysis approach, we further dwell on the findings of some of these studies.

Overall, the dynamic analyses on M\&As provide mixed results: some studies found improved performance, others reported no improvement, while a handful of studies showed a deterioration in performance. In the first category, Cornett and Tehranian (1992) showed that the merged banks outperform the banking industry. Their better performance appeared to result from improvements in the ability to attract loans and deposits, in employee productivity, and in profitable asset growth. Healy et al. (1992) examined post-acquisition operating performance of merged firms and found that these had significant improvements in asset productivity relative to their industries after the merger, leading to higher post-merger 
operating cash flow returns. Ramaswamy (1997) reached the conclusion that mergers between banks exhibiting similar strategic characteristics resulted in better performance than those involving strategically profitability ratios associated with the M\&A operations. All the cited studies involved US banks. In Europe, Altunbas and Ibanez (2004), after the examination of the impact of strategic similarities between bidders and targets on post-merger financial performance, reported that, on average, bank mergers resulted in improved return on equity. Focarelli et al. (2002) found that mergers of Italian banks resulted in improved return on equity because of a decrease in capital while acquisitions leading to improved lending policies resulted in higher profits. They suggest the separate examination of mergers and acquisitions, as they are driven by different factors. Campa and Hernando (2005) concluded that their paper provided evidence on changes in operating performance for the mergers involving banks, namely significant improvements in target banks' performance (return on equity increased by an average of $7 \%$ ), beginning on average two years after the transaction was completed. After having investigating long term effects on the target banks in 17 countries in Central and Eastern Europe and the Commonwealth of Independent States, Fritsch (2007) found that though the absolute values of profitability and efficiency of the target banks three years after the acquisition did not differ from those of domestic banks not involved in M\&A activities, the improvements in performance and loan growth were significantly better in the post merger phase.

A great number of studies found no evidence of any performance improvement associated with the M\&As. Correa (2008) found there was no positive performance effect in the first two years after a cross-border acquisitions. He stated that profitability was affected by a reduction in the net interest margin and by the lack of cost-efficiency gains. Vander Vennet (2002) found no improvements in cost efficiency and return on assets for European target banks on the first year after an acquisition. While Pilloff (1996) reported no significant change in post-merger return on equity of US banks, DeLong and Deyoung (2007) concluded the same - no evidence of clear positive effects of M\&A operations on the performance of the selected US banks. Badreldin and Kalhoefer (2009) found no clear effect on the profitability of the Egyptian banks, but only a minor positive effect on their credit risk position.

Some studies reported a deterioration of performance induced by the bank M\&As. Findings by Beccalli and Frantz (2008) showed that European M\&A operations were associated with a slight deterioration in return on equity in the 1-6 years after the deal (in comparison to the $3 / 6$ years prior to the deal). Still, banks involved in mergers and acquisitions were more profitable than their peers not involved in M\&As. Knapp et al. (2005), in their study of the financial performance of 80 US bank holding company mergers, found that the merged entity experienced a profitability below the industry average.

As our paper includes M\&A operations under the form of bank privatization, we also reviewed some studies dealing with this subject in developing countries (mainly Eastern Europe). Bonin et al. (2003) found that foreign-owned banks are most efficient and government-owned banks are least efficient. In addition, their research showed that early privatized banks are more efficient than later-privatized banks. Their findings are consistent with the ones of Clarke et al. (2005) which reported that although bank privatization usually improves bank efficiency, gains are greater when the government fully relinquishes control, when banks are privatized to strategic investors, when foreign banks are allowed to participate in the privatization process and when the government does not restrict competition. 


\section{Accounting Ratios as Profitability Measures}

This paper analyses banking performance as a bank's capacity to generate sustainable profitability. Profitability offers clues about a bank's ability to undertake risks and to expand its activity. It is a bank's first line of defense against unexpected losses, as it strengthens its capital position. The most common way of assessing profitability is by using the traditional accounting measures: return on equity (ROE) and return on assets (ROA). In addition, given the importance of the intermediation function for banks, net interest margin is typically monitored (ECB 2010).

The most popular measure of bank's performance is ROE as it is considered a critical performance indicator by both investors and management (Lindblom and Von Koch 2002). It divides the net income for the year by average total equity. ROE constitutes the most poignant expression of profit, highlighting the results of bank management in its entirety and indicating to shareholders the efficiency level of their investments (Cocriş and Chirleşan 2007). The most important advantages of ROE are: (a) it proposes a direct assessment of the financial return of a shareholder's investment; (b) it is easily available for analysts, only relying upon public information; and (c) it allows for comparison between different companies or different sectors of the economy (ECB 2010). Still, there are some shortcomings deriving from its use. Mainly, the ratio relies on the properties of accrual accounting to assess performance (Beccalli and Frantz 2008), hence it is affected by the accounting method used for recording the M\&A or the method used to finance the M\&A. In addition, it is subject to certain accounting choices that are left at the discretion of bank's management.

Many studies decompose ROE into its main drivers, the so-called DuPont analysis, as it allows an analysis of the components affecting profitability and facilitates trend analysis which is useful for detecting the source of a shift in profitability and taking corrective action before it is too late (Walker 2007). The DuPont model firstly breaks down ROE into two elements: the return on assets (ROA) and the financial leverage. ROE is ROA multiplied by the financial leverage.

The return on assets is the net income for the year divided by total average assets. ROA reflects the profitability of all the capital engaged in the operating activities (Mironiuc 2006). A higher value of ROA confirms that banks have appropriately formed their assets portfolio, contributing to higher financial results. Meeks and Meeks (1981) argue that of all the accounting measures of profitability, ROA is the least sensitive to the upward or downward estimation bias that can be induced by changes in leverage or bargaining power resulting from a merger. In other words, ROA is considered a more reliable profitability indicator than $\mathrm{ROE}$, in terms of efficiency performance, since it is adjusted for the leverage effect. Financial leverage (FL) divides total assets by total equity and therefore indicates the total assets banks have available per unit of equity invested by the shareholders. Sometimes, the inverse of the financial leverage, also known as equity ratio (ER), can be used. Equity ratio shows the portion of total assets financed by stockholders and not by creditors. It reflects the bankruptcy risk of the bank (Badreldin 2009).

Further on, ROA is decomposed into two components: net profit margin (NPM) which divides net income by total revenues and asset turnover (ATO) which shows the connection between total revenues and total (average) assets. Consequently, ROE equals NPM multiplied by ATO multiplied by FL.

The other accounting measure of profitability used in this paper is net interest margin (NIM). Computed as the difference between interest income and interest expenses over total assets, NIM shows the amount by which the interest received from the loan portfolio exceeds the interest paid on deposits or 
borrowed funds. It is a key indicator of asset productivity since a high NIM is indicative of effective use of earning assets and sensible mix of interest-bearing liabilities (Brissimis et al. 2007).

\section{Data Set, Sample and Methodology}

The data set is obtained by combining three sources: Zephyr database provided by Bureau van Dijk for data on the M\&A operations; Bankscope for balance sheet and profit and loss data of some of the banks involved in M\&A operations (M\&A sample) and financial statements provided by The Romanian National Trade Register Office where data on Bankscope were not available.

In this paper we examine the profitability of Romanian banks having taken part in M\&A activities in a period between 1998 and 2008. The sample is limited to target banks located in Romania. Moreover, it excludes banks that are not commercial, such as cooperative and savings banks in order to obtain a relatively homogeneous group of banks. The list of M\&A transactions extracted from Zephyr database was reduced to completed transactions which meant a sample of 96 transactions. For further analysis, we excluded from the sample the deals in which the target bank's control was not transferred to the acquirer and the ones representing intra-group transactions. The final sample comprised 12 transactions, out of which two were mergers and ten were acquisitions (including two bank privatizations). Table 1 presents the 12 transactions and the banks involved.

Although the size of the sample is relatively small compared to other studies conducted in the United States or Europe, we must underline that the total number of $M \& A$ in the Romanian banking sector is not quite as large as other countries, with a total number of banks at time of publication of 42 banks (NBR 2010). In addition, we considered the final sample of 12 deals satisfactory as it includes all the M\&A operations involving Romanian target banks in the aforementioned period and also reliable in comparison to prior accounting studies that were conducted in significantly larger markets: USA and EU (see Healy et al. 1992: n = 50; Cornett and Tehranian 1992: $\mathrm{n}=30$; Mylonidis and Kelnikola 2005: $n=9$, among others).

The accounting ratios were computed for a period of three years after the M\&A as many researchers (Rhoades 1993) and bank analysts suggest investigating the postmerger performance of banks for a period of 3 years. The year of the deal itself is left out of the analysis as it is strongly affected by the accounting practices used to report the M\&A. Hence, the results could be have been seriously distorted.

As far as the accounts used were concerned, we used the consolidated ones, where available. We also preferred the financial statements prepared in accordance with IAS/IFRS, but in some cases such information was not available, so we used data reported under the Romanian accounting standards (applicable for credit institutions, either harmonized with the European accounting directives and IAS for the years between 2000-2005 or compliant with the European accounting directives for the period between 2006-2010). In some situations, IAS/IFRS data were available for only one or two years out of the three selected, while for the remaining period were available in Romanian standards. In such cases we used Romanian standards for the whole period. 
Table 1 Descriptive of Transactions Selected in the Sample

\begin{tabular}{|c|c|c|c|c|c|}
\hline & $\begin{array}{l}\text { Year of } \\
\text { transaction }\end{array}$ & $\begin{array}{l}\text { Type of } \\
\text { transaction }\end{array}$ & Target & Acquirer & Resulting entity \\
\hline 1 & 1999 & Privatization & BRD & $\begin{array}{l}\text { Groupe Societe } \\
\text { Generale }\end{array}$ & BRD-GSG SA \\
\hline 2 & 2000 & Acquisition & Finansbank & FIBA Group & $\begin{array}{l}\text { Credit Europe Bank } \\
\text { Romania SA }\end{array}$ \\
\hline 3 & 2000 & Acquisition & PaterBank & Piraeus Bank & $\begin{array}{l}\text { Piraeus Bank } \\
\text { Romania SA } \\
\end{array}$ \\
\hline 4 & 2002 & Merger & $\begin{array}{l}\text { Banca Agricola } \\
\text { Raiffeisen }\end{array}$ & Raiffeisenbank & $\begin{array}{l}\text { Raiffeisen Bank } \\
\text { Romania SA }\end{array}$ \\
\hline 5 & 2003 & Acquisition & $\begin{array}{l}\text { Banca } \\
\text { Romaneasca }\end{array}$ & $\begin{array}{l}\text { National Bank of } \\
\text { Greece }\end{array}$ & $\begin{array}{l}\text { Banca Romaneasca } \\
\text { SA membra a } \\
\text { Grupului National } \\
\text { Bank of Greece }\end{array}$ \\
\hline 6 & 2004 & Acquisition & RoBank & OTP Hungary & $\begin{array}{l}\text { OTP Bank Romania } \\
\text { SA }\end{array}$ \\
\hline 7 & 2006 & Acquisition & $\begin{array}{l}\text { Romexterra } \\
\text { Bank }\end{array}$ & MKB Hungary & $\begin{array}{l}\text { MKB Romexterra } \\
\text { Romania SA }\end{array}$ \\
\hline 8 & 2006 & Acquisition & Eurombank & Leumi Group & $\begin{array}{l}\text { Bank Leumi Romania } \\
\text { SA }\end{array}$ \\
\hline 9 & 2006 & Acquisition & Mindbank & ATE Bank & $\begin{array}{l}\text { ATE Bank Romania } \\
\text { SA }\end{array}$ \\
\hline 10 & 2006 & Acquisition & Daewoo Bank & $\begin{array}{l}\text { Cassa di } \\
\text { Risparmio di } \\
\text { Firenze SpA }\end{array}$ & $\begin{array}{l}\text { Banca CR Firenze } \\
\text { Romania SA }\end{array}$ \\
\hline 11 & 2006 & Privatization & $\begin{array}{l}\text { Banca } \\
\text { Comerciala } \\
\text { Romana }\end{array}$ & Erste Bank & $\begin{array}{l}\text { Banca Comerciala } \\
\text { Romana SA }\end{array}$ \\
\hline 12 & 2007 & Merger & $\begin{array}{l}\text { UniCredit } \\
\text { Romania }\end{array}$ & HVB Tiriac Bank & $\begin{array}{l}\text { UniCredit Tiriac Bank } \\
\text { SA }\end{array}$ \\
\hline
\end{tabular}

Because the first deal in the sample took place in 1999, the first year for which the accounting ratios were computed was 2000, the last year being 2010. The year 2007 marked the onset of the worldwide financial turmoil. Therefore, we separated the sample into two sub-samples: sample A contains the deals taking place before 2006 (meaning 6 deals) which locates the post-M\&A 3-year period between 2000 and 2007. Sample B comprises the deals that took place after 2006 (the remaining 6 deals) which locates the post-M\&A 3-year period between 2007 and 2010. In the case of OTP Bank Romania, the acquisition took place in 2004, hence the 3 -year period was 2005-2007. This bank was included in the first sample.
ROA and ROE were calculated using the net income as a percentage of the average total assets and the net income as a percentage of the average common stock equity respectively. In addition, NIM was computed as the difference between interest income and interest expenses over total average interest-bearing assets. Post-merger performances of target banks were compared to those obtained by the whole industry for each of the 3 years and for the whole period. Mean ratios, but also median values were calculated as accounting ratios are often susceptible to outliers (in some cases, banks with extraordinarily high or low results distorted the mean values). 


\section{Empirical Results}

In this section, we discuss the results of the empirical tests. Tables $2 \mathrm{a}-2 \mathrm{~g}$ report the postM\&A financial accounting ratios for the merged banks and the corresponding accounting profitability ratios for the whole industry. The mean and median figures correspond to a 3-year period for both sample A/B and industry and are computed based on the data available on Bankscope, the official reports published by the National Bank of Romania and own calculations. The ratios displayed for the industry take into account the profitability of the whole 42 banks representing the Romanian banking system.

During the 3 years after the M\&As, the sample A mean return on assets (ROA) is $1.09 \%$ below industry, while the median
ROA, although below industry, is significantly closer to the industry median $-0.44 \%$ below industry (table $2 \mathrm{a}$ - panel A). This ratio shows that the merged banks underperforme the industry in all 3 years with better results in the $3^{\text {rd }}$ year (bank median is just $0.16 \%$ below industry) and the worst results in the $2^{\text {nd }}$ year (in absolute figures, bank median is $0.58 \%$ below industry). For sample B banks, median ROA is much closer to the industry median $(0.12 \%$ below industry), the merged banks outperforming the industry in the $3^{\text {rd }}$ year when the sample B median ROA is $0.48 \%$ above the industry (table 2a-panel B). Overall, the evolution (rise or decline) of median ROA for both samples during the 3year post-M\&A period could be explained by the superior dynamics (faster or slower) of average aggregate assets as compared with the net income.

Table 2a Bank and Industry Mean/Median Annual ROA for 12 Target Banks in Years after the M\&A

\begin{tabular}{|c|c|c|c|c|c|c|}
\hline $\begin{array}{c}\text { Year relative to } \\
\text { merger\&acquisition }\end{array}$ & Bank mean & \multicolumn{1}{|c|}{$\begin{array}{c}\text { Industry } \\
\text { mean }\end{array}$} & $\begin{array}{c}\text { Bank } \\
\text { median }\end{array}$ & $\begin{array}{c}\text { Industry } \\
\text { median }\end{array}$ & $\begin{array}{c}\text { Number of } \\
\text { observations }\end{array}$ \\
\hline 1 & \multicolumn{4}{|c|}{ Panel A - post M\&A 1-3 year before 2007 } & \\
\hline 2 & 0,90 & 2,10 & 1,33 & 1,90 & 6 \\
\hline 3 & 0,70 & 2,25 & 1,72 & 2,30 & 6 \\
\hline $\begin{array}{c}\text { Mean annual } \\
\text { performance for year 1- } \\
3\end{array}$ & 1,34 & 1,85 & 1,74 & 1,90 & 6 \\
\hline \multirow{2}{*}{0,98} & 2,07 & 1,60 & 2,03 & \\
\hline 2 & Panel B - post M\&A 1-3 year after 2007 & \\
\hline 3 & 0,54 & 1,31 & 0,87 & 1,31 & 6 \\
\hline $\begin{array}{c}\text { Mean annual } \\
\text { performance for year 1- }\end{array}$ & 0,16 & 0,93 & 0,52 & 0,93 & 6 \\
\hline 3 & $-2,89$ & 0,05 & 0,53 & 0,05 & 6 \\
\hline
\end{tabular}

ROE fluctuates over the period under review for both samples (table 2b). The significant positive evolution noticed for the median ROE in the $2^{\text {nd }}$ year after the merger $\left(2^{\text {nd }}\right.$ year ratio is almost double than the $1^{\text {st }}$ year one) is largely due to the faster rate of growth recorded by the net income comparing to the equity dynamics. This pace slows considerably in the $3^{\text {rd }}$ year when median ROE shrinks by $40.12 \%$. Nevertheless, sample A median ROE remains at a range between $8 \%$ to $16 \%$ (on average, the median 
9 Journal of Eastern Europe Research in Business \& Economics

is $3.74 \%$ below industry). In the meantime, for sample B banks, median ROE records a sharp decline to values ranging between 2$4 \%$. The $2^{\text {nd }}$ year shows a significant decrease (the relative change is $-46.93 \%$ ), while the $3^{\text {rd }}$ year shows a surprising recovery (the relative change is $29.33 \%$ ). This evolution is ascribed to the dramatic decrease of net income due to the financial crisis (which caused higher provisioning costs attributable to the rise in non-performing loans, and lower returns on investments in government securities - NBR [a] 2010) that affected the whole industry (in this case, further analysis needs to be done in order to separate the M\&A impact on bank performance from the impact of the global financial crisis). On average, sample B merged banks underperform the industry by $4.78 \%$, but manage to outperform it in the $3^{\text {rd }}$ year by $2.33 \%$.

Table 2b Bank and Industry Mean/Median Annual ROE for 12 Target Banks in Years after the M\&A

\begin{tabular}{|c|c|c|c|c|c|}
\hline $\begin{array}{c}\text { Year relative to } \\
\text { merger\&acquisition }\end{array}$ & $\begin{array}{c}\text { Bank } \\
\text { mean }\end{array}$ & $\begin{array}{c}\text { Industry } \\
\text { mean }\end{array}$ & $\begin{array}{c}\text { Bank } \\
\text { median }\end{array}$ & $\begin{array}{c}\text { Industry } \\
\text { median }\end{array}$ & $\begin{array}{c}\text { Number of } \\
\text { observations }\end{array}$ \\
\hline & \multicolumn{6}{|c|}{ Panel A - post M\&A 1-3 year before 2007 } & \\
\hline 1 & 8,03 & 15,66 & 8,13 & 14,15 & 6 \\
\hline 2 & 3,69 & 16,49 & 16,20 & 16,95 & 6 \\
\hline 3 & 10,38 & 14,01 & 9,70 & 14,15 & 6 \\
\hline $\begin{array}{c}\text { Mean annual } \\
\text { performance for year } \\
1-3\end{array}$ & 7,37 & 15,39 & 11,34 & 15,08 & \\
\hline & & & & & \\
\hline 1 & Panel B - post M\&A 1-3 year after 2007 & 6 \\
\hline 2 & 5,89 & 13,22 & 4,24 & 13,22 & 6 \\
\hline 3 & 1,35 & 9,95 & 2,25 & 9,95 & \\
\hline $\begin{array}{c}\text { Mean annual } \\
\text { performance for year }\end{array}$ & $-34,84$ & 0,58 & 2,91 & 0,58 & \\
\hline $1-3$ & $-9,20$ & 7,92 & 3,13 & 7,92 & \\
\hline
\end{tabular}

Both median ROA and ROE computed for sample A banks are situated below industry median, at almost the same level (in relative figures, ROA stands $21.18 \%$ below industry while ROE stands $24.8 \%$ below industry). For sample B, median ROE for 1-3 year period declines dramatically under the industry median (60.40\% below industry) while median ROA is situated closer to the industry ratio ( $15.79 \%$ below).

Median equity ratio (ER) for sample A banks shows a downward trend (from $16.19 \%$ in the $1^{\text {st }}$ year to $10.31 \%$ in the $3^{\text {rd }}$ year) ascribed to a faster growth rate recorded by bank assets as compared with bank equity (table 2c). This evolution implies a reduction of the degree in which banks use shareholders' equity to finance their assets. Median financial leverage (FL) confirms it: merged banks seem to be more levered than the industry (in relative figures, bank median is $6.78 \%$ above industry - table 2d). A decrease of ER would normally lead to an increase in ROE. For sample A banks this happens only during the $2^{\text {nd }}$ year of the postM\&A period. Due to the evolution of other indicators (mainly, net income), the median ROE declined in the $3^{\text {rd }}$ year by $40.12 \%$ (relative change). 
Sample B banks also report a negative trend of the median ER for the first 2 years after the M\&As and a slight recovery in the $3^{\text {rd }}$. The latter evolution is due to a nominal decline in assets (something not quite desirable during a recession) which took place at a faster pace than the rise in the volume of equity. Correspondingly, on average, the median FL confirms that merged banks are less levered than industry (by a $15.26 \%$ - relative figure) which illustrates their unused debt.

Table 2c Bank and Industry Mean/Median Annual ER for 12 Target Banks in Years after the M\&A

\begin{tabular}{|c|c|c|c|c|c|}
\hline $\begin{array}{c}\text { Year relative to } \\
\text { merger\&acquisition }\end{array}$ & Bank mean & $\begin{array}{c}\text { Industry } \\
\text { mean }\end{array}$ & $\begin{array}{c}\text { Bank } \\
\text { median }\end{array}$ & $\begin{array}{l}\text { Industry } \\
\text { median }\end{array}$ & $\begin{array}{c}\text { Number of } \\
\text { observations }\end{array}$ \\
\hline & \multicolumn{4}{|c|}{ Panel A - post M\&A 1-3 year before 2007} & \\
\hline 1 & 18,46 & 13,67 & 16,19 & 13,92 & 6 \\
\hline 2 & 13,88 & 13,44 & 12,94 & 13,51 & 6 \\
\hline 3 & 11,89 & 12,90 & 10,31 & 13,35 & 6 \\
\hline \multirow{2}{*}{$\begin{array}{c}\text { Mean annual } \\
\text { performance for year 1-3 }\end{array}$} & 14,74 & 13,34 & 13,15 & 13,59 & \\
\hline & \multicolumn{4}{|c|}{ Panel B - post M\&A 1-3 year after 2007} & \\
\hline 1 & 16,24 & 10,06 & 12,74 & 10,06 & 6 \\
\hline 2 & 13,85 & 9,03 & 10,26 & 9,03 & 6 \\
\hline 3 & 12,58 & 8,95 & 10,47 & 8,95 & 6 \\
\hline $\begin{array}{c}\text { Mean annual } \\
\text { performance for year 1-3 }\end{array}$ & 14,22 & 9,35 & 11,16 & 9,35 & \\
\hline
\end{tabular}

Table 2d Bank and Industry Mean/Median Annual FL for 12 Target Banks in Years after the M\&A

\begin{tabular}{|c|c|c|c|c|c|}
\hline $\begin{array}{c}\text { Year relative to } \\
\text { merger\&acquisition }\end{array}$ & \multicolumn{1}{c|}{$\begin{array}{c}\text { Bank } \\
\text { mean }\end{array}$} & $\begin{array}{c}\text { Industry } \\
\text { mean }\end{array}$ & $\begin{array}{c}\text { Bank } \\
\text { median }\end{array}$ & $\begin{array}{c}\text { Industry } \\
\text { median }\end{array}$ & $\begin{array}{c}\text { Number of } \\
\text { observations }\end{array}$ \\
\hline 1 & \multicolumn{2}{|c|}{ Panel A - post M\&A $1-3$ year before 2007 } & \\
\hline 2 & 7,41 & 7,33 & 6,17 & 7,18 & 6 \\
\hline 3 & 7,82 & 7,47 & 7,73 & 7,42 & 6 \\
\hline $\begin{array}{c}\text { Mean annual } \\
\text { performance for year 1- }\end{array}$ & 8,85 & 7,85 & 9,70 & 7,51 & 6 \\
\hline 3 & 8,03 & 7,55 & 7,87 & 7,37 & \\
\hline 1 & Panel B - post M\&A $1-3$ year after 2007 & \\
\hline 2 & 7,73 & 9,98 & 7,93 & 9,98 & 6 \\
\hline 3 & 9,11 & 11,09 & 9,76 & 11,09 & 6 \\
\hline Mean annual & 8,78 & 11,19 & 9,63 & 11,19 & 6 \\
\hline performance for year 1- & & 10,75 & 9,11 & 10,75 & \\
\hline
\end{tabular}


The median net profit margin (NPM) suffered an evident decline in the $2^{\text {nd }}$ year for sample A banks, but recovered in the $3^{\text {rd }}$ year to stabilize at a level situated between those recorded in the $1^{\text {st }}$ and $2^{\text {nd }}$ year $\left(1^{\text {st }}\right.$ year $4.68 \% ; 2^{\text {nd }}$ year $-2.48 \%$ ) (table $2 \mathrm{e}$ ). The median NPM for sample B banks shows a significant decrease in the second year, stabilizing at a level around $5 \%$ in the $3^{\text {rd }}$ year (relative change: $-2.16 \%$ ). Unfortunately, incomplete data hampered calculating industry means and medians, but the available data indicates that sample $\mathrm{B}$ banks strongly underperform the industry. The NPM evolution is one of the most important drivers of ROE, explaining its fluctuant unfolding.

Table 2e Bank and Industry Mean/Median Annual NPM for 12 Target Banks in Years after the M\&A

\begin{tabular}{|c|c|c|c|c|c|}
\hline $\begin{array}{c}\text { Year relative to } \\
\text { merger\&acquisition }\end{array}$ & $\begin{array}{l}\text { Bank } \\
\text { mean }\end{array}$ & $\begin{array}{l}\text { Industry } \\
\text { mean }\end{array}$ & $\begin{array}{c}\text { Bank } \\
\text { median }\end{array}$ & $\begin{array}{l}\text { Industry } \\
\text { median }\end{array}$ & $\begin{array}{c}\text { Number of } \\
\text { observations }\end{array}$ \\
\hline & \multicolumn{4}{|c|}{ Panel A - post M\&A 1-3 year before 2007} & \\
\hline 1 & 0,86 & -- & 4,68 & -- & 6 \\
\hline 2 & 0,15 & -- & 2,48 & -- & 6 \\
\hline 3 & 5,24 & -- & 3,26 & -- & 6 \\
\hline \multirow[t]{2}{*}{$\begin{array}{c}\text { Mean annual } \\
\text { performance for year } \\
1-3\end{array}$} & 2,08 & -- & 3,47 & -- & \\
\hline & \multicolumn{3}{|c|}{$\begin{array}{c}\text { Panel B - post M\&A 1-3 year } \\
\text { after } 2007\end{array}$} & & \\
\hline 1 & 3,28 & 15,72 & 7,29 & 15,72 & 6 \\
\hline 2 & 0,58 & 11,32 & 5,09 & 11,32 & 6 \\
\hline 3 & $-6,18$ & -- & 4,98 & -- & 6 \\
\hline $\begin{array}{c}\text { Mean annual } \\
\text { performance for year } \\
1-3\end{array}$ & $-0,77$ & 13,52 & 5,79 & 13,52 & \\
\hline
\end{tabular}

Regarding the asset turnover (ATO), sample A banks record a relative change of $-16.06 \%$ in the $2^{\text {nd }}$ year after the M\&As, but in the $3^{\text {rd }}$ year there is a slight increase of $2.16 \%$. Median ATO for sample B banks shows a significant increase over the 3-year period caused mainly by a nominal decline in assets (during the financial crisis, banks sold fixed assets to improve their short-term financial position) and not by a rise in operating revenues. Nevertheless, the available data show the merging banks strongly outperforming the industry in terms of the efficiency of assets utilization (table 2f). 
Table 2f Bank and Industry Mean/Median Annual ATO for 12 Target Banks in Years after the M\&A

\begin{tabular}{|c|c|c|c|c|c|c|}
\hline $\begin{array}{c}\text { Year relative to } \\
\text { merger\&acquisition }\end{array}$ & Bank mean & \multicolumn{1}{|c|}{$\begin{array}{c}\text { Industry } \\
\text { mean }\end{array}$} & $\begin{array}{c}\text { Bank } \\
\text { median }\end{array}$ & $\begin{array}{c}\text { Industry } \\
\text { median }\end{array}$ & $\begin{array}{c}\text { Number of } \\
\text { observations }\end{array}$ \\
\hline 1 & \multicolumn{4}{|c|}{ Panel A - post M\&A 1-3 year before 2007 } & \\
\hline 2 & 29,10 & -- & 21,54 & -- & 6 \\
\hline 3 & 30,40 & -- & 18,08 & -- & 6 \\
\hline $\begin{array}{c}\text { Mean annual } \\
\text { performance for year 1- } \\
3\end{array}$ & 33,94 & -- & 18,47 & -- & 6 \\
\hline & 31,15 & -- & 19,36 & -- & \\
\hline 1 & Panel B - post M\&A 1-3 year after 2007 & \\
\hline 2 & 9,05 & 7,30 & 9,10 & 7,30 & 6 \\
\hline 3 & 11,13 & 8,06 & 11,22 & 8,06 & 6 \\
\hline $\begin{array}{c}\text { Mean annual } \\
\text { performance for year 1- }\end{array}$ & 17,38 & -- & 13,50 & -- & 6 \\
\hline 3 & 12,52 & 7,68 & 11,27 & 7,68 & \\
\hline
\end{tabular}

Both sample A and B banks record a positive trend of median net interest margin (NIM) over the 3-year period. This evolution shows that merging banks generate higher net interest income as a portion of earning assets every year. While for sample A banks there is insignificant change from one year to another, and the sample median NIM is very similar to the industry median, sample B banks post a more meaningful rise of the ratio in the $3^{\text {rd }}$ year (a relative change of $39.16 \%$ ). This could be attributable to an increase in the spread between lending and deposit rates due to a general policy of raising interest margins for lei and foreign currency. Overall, sample B banks outperform industry (median NIM is 56.42\% above industry) as shown in table $2 \mathrm{~g}$.

Table 2g Bank and industry mean/median annual NIM for 12 target banks in years after the M\&A

\begin{tabular}{|c|c|c|c|c|c|}
\hline $\begin{array}{c}\text { Year relative to } \\
\text { merger\&acquisition }\end{array}$ & Bank mean & $\begin{array}{l}\text { Industry } \\
\text { mean }\end{array}$ & $\begin{array}{c}\text { Bank } \\
\text { median }\end{array}$ & $\begin{array}{c}\text { Industry } \\
\text { median }\end{array}$ & $\begin{array}{c}\text { Number of } \\
\text { observations }\end{array}$ \\
\hline & \multicolumn{4}{|c|}{ Panel A - post M\&A 1-3 year before 2007} & \\
\hline 1 & 8,23 & 7,54 & 7,25 & 7,47 & 6 \\
\hline 2 & 7,90 & 7,81 & 7,37 & 8,30 & 6 \\
\hline 3 & 8,09 & 6,45 & 7,71 & 6,57 & 6 \\
\hline \multirow[t]{2}{*}{$\begin{array}{l}\text { Mean annual performance } \\
\text { for year } 1-3\end{array}$} & 8,07 & 7,27 & 7,44 & 7,45 & \\
\hline & \multicolumn{4}{|c|}{ Panel B - post M\&A 1-3 year after 2007} & \\
\hline 1 & 7,15 & 4,60 & 6,41 & 4,60 & 6 \\
\hline 2 & 7,82 & 4,67 & 6,64 & 4,67 & 6 \\
\hline 3 & 12,53 & 4,98 & 9,24 & 4,98 & 6 \\
\hline $\begin{array}{l}\text { Mean annual performance } \\
\text { for year } 1-3\end{array}$ & 9,17 & 4,75 & 7,43 & 4,75 & \\
\hline
\end{tabular}




\section{Conclusions}

The present study attempts to shed further light on the effects of M\&As in the Romanian banking system. It focuses on target banks located in Romania and involved in mergers and acquisitions between 1998 and 2008. It follows a methodology of assessing performance in terms of bank profitability using accounting information derived from annual financial statements. Although accounting data is considered an imperfect measure of economic performance (Healy et al., 1992) because it can be affected by certain manipulative actions, the researchers still find it useful and argue that if there is any M\&A impact on bank performance, this is bound to appear in the published accounts.

The complete findings of this paper are mixed. On one hand, bank M\&A in Romania does not result in improved ROE or ROA in the post M\&A 3-year period under review. On the other hand, both samples report median NIM above the industry median. Regarding ROE, sample banks underperform industry in each of the 3 years. The targets' overall performance in terms of ROE is not significantly different for the two samples. Both are situated below industry, but sample A (containing the deals taking place before 2006) reports a median ROE closer to the industry median $(24.8 \%$ below industry median) than the one of the second sample (comprising deals taking place after 2006) which shows a median ROE situated $60.48 \%$ below industry. Nevertheless, sample B results are worse than sample A's, ranging between $2 \%$ and $4 \%$ (72.40\% below sample A banks median ROE). This latter result is strongly influenced by the effects of the global financial crisis and the Romanian economic crisis. Although the researchers agree that further analyses is required to separate the M\&A impact on bank performance from the impact of the global financial crisis, these results are considered relevant because they are compared with the industry aggregate ratios (the whole banking system being affected by the crisis). The present findings are in contradiction to
Altunbas et al.'s (2004) or Campa and Hernando's (2005) findings that bank M\&A results in improved ROE, but confirm the results of other studies (Beccalli and Frantz, 2008) that show a deterioration of performance induced by the bank M\&As.

Regarding NIM, both samples post increasing result from one year to another, sample $B$ banks strongly outperforming the industry. The overall results of the both sample are very similar (sample A median NIM is 7.44\%, while sample B median NIM is $7.43 \%$ ).

\section{References}

Asaftei, G. \& Kumbhakar, S. C. (2007). "Regulation and Efficiency in Transition: The Case of Romanian Banks," Journal of Regulatory Economics, vol. 33, no 3, 253-282.

Badreldin, A. \& Kalhoefer, C. (2009). "The Effect of Mergers and Acquisitions on Bank Performance in Egypt," Working Paper Series, German University in Cairo.

Badreldin, A. M. (2009). "Measuring the Performance of Islamic Banks by Adapting Conventional Ratios," Working Paper Series, German University in Cairo.

Beccalli, E. \& Frantz, P. (2008). “Do M\&As in the EU Banking Industry Lead to an Increase in Performance?," Universita degli Studi di Macerata,Quaderno di Dipartimento n. 50.

Berger, A. N., Demsetz, R. S. \& Strahan, P. E. (1999). "The Consolidation of the Financial Services Industry: Causes, Consequences, and Implications for the Future," Journal of Banking and Finance 23, forthcoming.

Berger, A. N. \& Humphrey, D. B. (1992). "Megamergers in Banking and the Use of Cost Efficiency as an Antitrust Defense," Antitrust Bulletin 37, 541- 600.

Bonin, J. P., Hasan, I. \& Wachtel, P. (2005). "Bank Performance, Efficiency and Ownership in Transition Countries," Journal 
of Banking and Finance, Volume 29, Issue 1, 31-53.

Bonin, J. \& Wachtel, P. (2003). "Financial Sector Development in Transition Economies: Lessons from the First Decade," Financial Markets, Institutions, and Instruments 12, 1-66.

Brissimis, S. N., Delis, M. D. \& Papanikolaou, N. I. (2007). "Exploring the Nexus between Banking Sector Reform and Performance: An Evidence from Newly Acceded EU Countries," Bank of Greece Working Paper.

Campa, J. M. \& Hernando, I. (2006). “M\&As Performance in the European Financial Industry," Journal of Banking and Finance 30, 3367-3392.

Clarke, G. R. G., Cull, R. \& Shirley, M. M. (2005). "Bank Privatization in Developing Countries: A Summary of Lessons and Findings," Journal of Banking \& Finance 29, 1905-1930.

Cocriș, V. \& Chirleşan, D. (2007). 'Management Bancar şi Analiza de Risc în Activitatea de Creditare,' Editura Universităţii «Al. I. Cuza », Iaşi.

Cornett, M. \& Tehranian, H. (1992). “Changes in Corporate Performance Associated with Bank Acquisitions," Journal of Financial Economics 31, 211-234.

Correa, R. (2009). "Cross-Border Bank Acquisitions: Is There a Performance Effect?," Board of Governors of the Federal Reserve System, International Finance Discussion Papers no 922.

Cybo-Ottone, A. \& Murgia, M. (2000). "Mergers and Shareholder Wealth in European Banking," Journal of Banking and Finance 24, 831-859.

Dardac, N. \& Moinescu, B. (2009). "The Third Wave of the Financial Crisis and its Ripple Effects on the Deterioration Risk of Romanian Banking Sector's Performance,"
Journal of Economic Computation and Economic Cybernetics Studies and Research 1, 23-40.

DeLong, G. \& DeYoung, R. (2007). "Learning by Observing: Information Spillovers in the Execution and Valuation of Commercial Bank M\&As," Journal of Finance 62, 181-216.

DeYoung, R., Evanoff, D. D. \& Molyneaux, P. (2009). "Mergers and Acquisitions of Financial Institutions: A Review of the Post2000 Literature," Journal of Financial Services Research 36, 86-110.

Ekkayokkaya, M., Holmes, P. \& Paudyal, K. (2009). "The Euro and the Changing Face of European Banking: Evidence from Mergers and Acquisitions," European Financial Management 15, 451-476.

European Central Bank (2010). "Beyond ROE-How to Measure Bank Performance," Appendix to the report on EU Banking Structures. September 2010.

Focarelli, D., Panetta, F. \& Salleo, C. (2002). "Why do Banks Merge?," Journal of Money, Credit and Banking, Vol. 34, No. 4, 1047-1066.

Fritsch, M. (2007). "Long Term Effects of Bank Acquisitions in Central and Eastern Europe," [Online], [Retrived August 15, 2011], http://ssrn.com/abstract $=1008838$

Gondor, M. \& Munteanu, A. (2010). "Romanian Banking Performance: An Outlook Provided by Data Envelopment Analysis," Revista Economica, no 6 (53), vol 1, 277-285.

Healy, P. M., Palepu, K. G. \& Ruback, R. S. (1992). "Does Corporate Performance Improve after Mergers?," Journal of Financial Economics 31, 135-175.

Huizinga, H. P., Nelissen, J. H. M. \& Vennet, R. V. (2001). "Efficiency Effects of Bank Mergers and Acquisitions in Europe," Working Paper Ghent University n. 106. 
Isărescu, M. (2008). "Romania in the Context of the Global Financial Crisis: An Overview," [Online], [Retrived August 20, 2011], http://www.bnr.ro/PublicationDocuments.a spx?icid $=6885$

Knapp, M., Gart, A. \& Chaudhry, M. (2005). "The Impact of Mean Reversion of Bank Profitability on Post-Merger Performance in the Banking Industry," Journal of Banking and Finance 30, 3503-3517.

Koetter, M. (2005). "Evaluating the German Bank Merger Wave," Deutsche Bundesbank Discussion Paper Series 2, Bank Financial Studies 2005-12.

Lindblom, T. \& Von Koch, C. (2002). "CrossBorder Bank Mergers and Acquisitions in the EU," The Service Industries Journal, Vol. 22, No. 4, 41-72.

Lozano-Vivas, A. \& Weill, L. (2009). "How Does Cross-Border Activity Affect the EU Banking Markets?," European Financial Management, December 2009.

Manole, V. \& Grigorian, D. A. (2002). "Determinants of Commercial Bank Performance in Transition: An Application of Data Envelopment Analysis," World Bank Policy Research Working Paper 2850.

Marques-Ibanez, D. \& Altunbas, Y. (2004). "Mergers and Acquisitions and Bank Performance in Europe the Role of Strategic Similarities," European Central Bank Working Paper Series No. 398.

Meeks, G. \& Meeks, J. G. (1981). "Profitability Measures as Indicators of Post-Merging Efficiency," Journal of Industrial Economics, 29.

Mironiuc, M. (2006). 'Analiză EconomicFinanciară,' Editura Sedcom Libris, Iași.

Mylonidis, N. \& Kelnikola, I. (2005). “Merging Activity in the Greek Banking System: A Financial Accounting Perspective," South-
Eastern Europe Journal of Economics 1, 121144.

National Bank of Romania (2000). Annual Report, [Online], [Retrived at July 25, 2011], http://www.bnr.ro/Publicatii-periodice204.aspx

National Bank of Romania (2007). Annual Report, [Online], [Retrived at July 25, 2011], http://www.bnr.ro/Publicatii-periodice204.aspx

National Bank of Romania (2008). Annual Report, [Online], [Retrived at July 25, 2011], http://www.bnr.ro/Publicatii-periodice204.aspx

National Bank of Romania [a] (2010). Financial Stability Report, [Online], [Retrived at July 25, 2011], http://www.bnr.ro/Publicatii-periodice204.aspx

National Bank of Romania [b] (2010). Annual Report, [Online], [Retrived at July 25, 2011], http://www.bnr.ro/Publicatii-periodice204.aspx

Pilloff, S. J. (1996). "Performance Changes and Shareholder Wealth Creation Associated with Mergers of Publicly Traded Banking Institutions," Journal of Money, Credit, and Banking 28, 294-310.

Ramaswamy, K. (1997). "The Performance Impact of Strategic Similarity in Horizontal Mergers: Evidence from the U.S. Banking Industry," The Academy of Management Journal, Vol. 40, No. 3, 697-715.

Rhoades, S. A. (1993). "Efficiency Effects of Horizontal (In-Market) Bank Mergers," Journal of Banking and Finance 17, 411-422.

Vander Vennet, R. (2002). Cross-Border Mergers in European Banking and Bank Efficiency, Ghent University Working Paper.

Walker, J. S. (2007). 'Using the DuPont Equation to Improve Your Bank's 
Journal of Eastern Europe Research in Business \& Economics 16

Performance,' Ambassador Financial Group Inc. Research, October 2007.

\section{Endnotes}

[1] See DeYoung, Evanoff and Molyneaux (2009) for a review of the handful of both American and European studies using this methodology, emerging after 2000. 